\title{
The Kosovo Model: A (Bad) Precedent for Conflict Management in the Caucasus?
}

\author{
Pierre Jolicoeur and Frederic Labarre *
}

\begin{abstract}
Resolution 1244 adopted by the United Nations Security Council (UNSC) in 1999 was conceived as an interim settlement to allow conflict de-escalation while postponing the search for a lasting solution to the Kosovo crisis. The final settlement should have been negotiated between Serbian authorities and representatives of the Kosovo Albanians and then endorsed by the UNSC, as stipulated in the resolution. However, Kosovo Albanians declared independence unilaterally in February 2008 and Kosovo was recognized as such by the United States and its allies. The Kosovo Albanians promptly abandoned the peace process.

Instead of an internationally-endorsed negotiated outcome, the Kosovo Albanians' initiative unilaterally imposed a political settlement on the mediating powers in complete disregard of UNSC authority that had placed Kosovo under international administration. The subsequent involvement of the International Court of Justice (ICJ) failed to resolve the remaining issues between Serbs and Kosovars.

In addition to creating a troubling legal precedent, the Kosovo example establishes a bad precedent for future conflict management initiatives, especially for ongoing conflicts in the Caucasus. Issues of concern include the viability of future interim agreements, good faith negotiations and the legitimacy and guarantees provided by the internationalization of conflicts, including the authority of international organizations, multilateral agencies and established legal standards. This paper draws parallels between the Kosovo example and territorial disputes in the Caucasus as well as the implications of the Kosovo model on conflict management processes.
\end{abstract}

Keywords: Conflict management, Kosovo, South Caucasus.

\section{Introduction}

This article focuses on conflict management as it has evolved between the end of the Cold War and since the unilateral declaration of independence (UDI) by the provisional authorities in Kosovo on 17 February 2008. As such, we can now speak of a post-UDI conflict-management practice and there is a risk that the post-Cold War conflict management methods that offered so much hope in terms of cooperative international problemsolving are waning. Whether or not this spirit will return depends on the mutual trust between the major powers and of those powers in the international conflict management system, characterized by interlocking multilateral international organizations such as the UN, the OSCE and NATO.

The argument proceeds from a short discussion of post-Cold War conflict management, its definition and practice as the antithesis of Cold War (or traditional) conflict

Pierre Jolicoeur, PhD, is Head of the Department of Political Science, Royal Military College of Canada, Kingston (Canada). Frederic Labarre, MA, is an International Program Manager at the Partnership for Peace Consortium in Germany. 
management and how it seemingly applied to Kosovo. It then analyses the significance of the Kosovo UDI as a break in the practice of conflict management. Three consequences follow from this break. First, incapacitating distrust of multilateralism owing to the unpredictability of outcomes. Second, suspicion of self-determination movements and small powers as being unable to follow the lead of great powers or the ordnances of international organizations. Third, return to an antecedent form of state-based conflict management, antithetical to the cooperative practice that evolved during the post-Cold War years that is now the new norm.

Conflict management, in the case of Kosovo, cannot be taken apart; it has to be seen as a whole. The diplomatic maneuvers that generated the Rambouillet Accords in March 1999, NATO's Operation Allied Force from March until June 1999, UN Security Council Resolution 1244 in June 1999, the Kosovo UDI on 17 February 2008 and the subsequent recognition of Kosovo's independence by certain Euro-Atlantic powers a few days later need to be understood in concert. The result is known as the "Kosovo Model" of conflict management. This article suggests that the consequences of this approach are nefarious for comparable international problems in other parts of the world, especially in the Caucasus. In fact, the Kosovo UDI and the Russo-Georgian war cannot be examined in isolation. For this reason, the final part of this essay will discuss the impact of the Kosovo Model on conflict management in the Caucasus.

\section{Post-Cold War Conflict Management}

During the Cold War, conflict management was mostly the purview of states. Mutual nuclear destruction by the United States and the USSR assured the peace, as did United Nations peacekeeping activities, preventing superpower confrontation in the non-aligned world. ${ }^{1}$ Realism was the dominant paradigm of international relations; multilateralism was nearly always subject to the interests of the competing alliances. Conflict was managed through high-level diplomacy and military deterrence (or action). This paradigm shifted in the aftermath of the fall of the Berlin Wall.

Free from ideological motivations, states now have a greater incentive to cooperate rather than confront one another. Unshackled by bipolar confrontation, the UN was then able to pursue its mission of managing conflict with renewed vigor. The number of General Assembly and Security Council resolutions rose, a testimony not only to the disorderly collapse of the Soviet Union and Yugoslavia, but to the corresponding desire by the UN membership to address the unrest. Mostly, however, conflict management evolved to include the principles of conflict prevention, peace operations (including enforcement) and post-conflict peacebuilding, buttressed by international law. To meet the securitization of these new issues, an international "civil society" emerged, empowered by non-governmental organizations, security think tanks and other associations. ${ }^{2}$

1 Sean M. Maloney, Canada and UN Peacekeeping: Cold War by Other Means, 1945-1970 (Toronto: Vanwell Publishing, 2002).

2 See Craufurd Goodwyn and Michael Nacht, eds., Beyond Government (Boulder: Westview Press, 1995). 
Conflict management was elevated to the multilateral level. States were expected to conform and adapt their behavior in accordance with the procedures of international organizations, such as voting rules for the UN General Assembly, the Security Council and its manifold agencies. Multilateralism made international relations more predictable, since the wealth of international organizations that in the post-Cold War world was accompanied by due process and an expectation of adherence to international legal regimes by states, groups and persons. ${ }^{3}$ A characterization of post-Cold War conflict management, detailed by UN Secretary General Boutros Boutros-Ghali in An Agenda for Peace (published in 1992 and amended in 1995, following the early post-Cold War peacekeeping setbacks of the UN), is illustrated in Figure 1, below.

\section{\begin{tabular}{|l|l|l} 
Conflict Prevention & Peacekeeping (and Enforcement) & Peacebuilding
\end{tabular}}

Figure 1: A Rudimentary Visualization of post-Cold War Conflict Management 19901995.

As early as 1995, the model ran into trouble; the inability of the United Nations to have its authority respected owed much to the lack of coercive power at its disposal. NATO became, for a time, the instrument of choice to enforce peace and UNSC decisions. This is all the more significant as UNSC decisions can be vetoed by two of its permanent members that are not members of NATO; Russia and China. The UNSC's NATO members (France, the United Kingdom and the United States) also have a fundamentally different conception of the state than its non-NATO members. To Robert Cooper, the former are part of the "post-modern" lot, who see states as having rights and obligations, whereas the latter "modern" states perceive a central authority's rights over its territory and population as inviolable. ${ }^{4}$ Disagreement in international fora between the latter and the former is a function of disagreement over human versus state rights.

This evolution also introduced the concept of "rogue states"; those that refuse to comply with the rules and norms of behavior of the international community. Conflict management reflected the international community's interest in achieving stable security on a number of new issues shaping the landscape of international relations, such as human rights, development, international trade and proliferation. ${ }^{5}$ When wars occur, the temptation to "let them burn," as Edward Luttwak once advocated in Foreign Affairs, becomes unacceptable to much of the international community: “...stable security can

3 Joseph S. Nye Jr., Understanding International Conflict, $6^{\text {th }}$ ed. (New York: Pearson-Longman, 2007), 279.

4 Robert Cooper, The Breaking of Nations: Order and Chaos in the $21^{\text {st }}$ Century (Toronto: McClelland and Stewart, 2004), 16-30.

5 See John Baylis and Steve Smith, The Globalization of World Politics, $2^{\text {nd }}$ ed. (Oxford: Oxford University Press, 1998). 
only be achieved by people and groups if they do not deprive others of it; this can be achieved if security is conceived as a process of emancipation." 6

"Emancipation" became a security issue at the individual, group and national level. We are only beginning to grasp how the expression of those grievances affected two cherished concepts of international politics: the respect for human and minority rights on the one hand, and the preservation of state authority (and territorial integrity) on the other. This is why it is argued that to mount

...armed multilateral intervention to right all such wrongs would be another principle of disorder... intervention is a matter of degree, with actions ranging from statements and limited economic measures at the low end of the spectrum to full-fledged invasions at the high end.

With Operation Allied Force by NATO's resolve to intervene in the humanitarian emergency in Kosovo, conflict management at the most coercive level had eschewed the UN and morphed into the model of Figure 2, below.

\begin{tabular}{|l|l|l|}
\hline Conflict Prevention (UN) & Enforcement (Unilateral or Allied) & Peacebuilding (UN) \\
\hline
\end{tabular}

Figure 2: A Rudimentary Visualization of post-Cold War Conflict Management from 1999.

Jettisoning peacekeeping and peace enforcement precipitated the soul-searching by the UN in the aftermath of Operation Allied Force as it struggled to stay relevant as an organization and as a model for managing conflict. According to Manuel Fröhling, three critical reports establish the failure of multilateral conflict management in the post-Cold War strategic environment: the Report of the Secretary General on the situation in Srebrenica, the Independent Inquiry into the Actions of the United Nations during the Genocide in Rwanda and the Report of the Panel on United Nations Peacekeeping Operations (also known as the Brahimi Report). All were issued between 15 November 1999 and 21 August 2000 in the wake of the Kosovo air raids. ${ }^{7}$

Operation Allied Force punctuated a decade of failed UN peace operations. As a case of humanitarian intervention, it was not legally sanctioned by the UNSC. Legitimiz-

6 Ibid., 255, quoting Booth and Wheeler.

7 Manuel Fröhlich, "Keeping Track of UN Peace-keeping: Suez, Srebrenica, Rwanda and the Brahimi Report," Max Planck Yearbook of United Nations Law 5 (2001): 187. The reports are respectively, A/54/549, S/1999/1257 and S/2000/809. The last report is the most important, because it reveals a strong tendency already evident during the 1990 s that peacekeeping could not be counted on to maintain peace, and if peace enforcement was the new task, the UN could not perform it well on its own and had to rely on regional organizations, such as NATO. Many UN members were not keen on having the UN engage in peace enforcement missions. This effectively re-oriented the focus on the internationalization of disputes and conflict management by the UN towards conflict prevention and post-conflict peace-building. 
ing action, as Katariina Simonen has argued, does not make it legal. ${ }^{8}$ Former Russian Prime Minister Yevgeni Primakov feared that the unilateral decision in favor of armed intervention confirmed a tendency to replace the UN as a conflict management apparatus. ${ }^{9}$ Primakov insisted that the use of force is acceptable only in cases of patent aggression against a UN Member State, which Kosovo was not. ${ }^{10}$ That is to say, not only did NATO knowingly defect from accepted UN rules of procedures and contemporary international law (especially from the Helsinki Final Act of 1975), but, in doing so, it gave the impression that Kosovo was indeed a sovereign state. With the attack on the Federal Republic of Yugoslavia (FRY) and Kosovo, NATO not only obliterated international legal customs, but also answered a characteristic desire of the international community — and its constituents - to retaliate against Serbia for the violence it had authorized against the Kosovar minority. ${ }^{11}$

On 10 June 1999, the UNSC issued Resolution 1244 (UNSCR 1244), aimed at resolving the humanitarian crisis unfolding in Kosovo. It set forth the principles of cessation of hostilities (annex 1 of the resolution) and of the future development of institutions based on a transitional international administration in Kosovo. The resolution was necessarily the result of a consensus among the five permanent member states of the UNSC.

The UNSC intended to resolve the humanitarian crisis while simultaneously preserving the territorial integrity of the FRY, that is, of Serbia and Montenegro, including Kosovo. UNSCR 1244 provided for "the establishment, pending a final settlement, of substantial autonomy and self-government in Kosovo, taking full account of annex 2 and of the Rambouillet accords (S/1999/648)". ${ }^{12}$ The Rambouillet Accords of March 1999 guaranteed Serbia's territorial integrity, as stipulated in Chapter 1 (Constitution), Chapter 1, Article 3 (the Federal Republic of Yugoslavia has competence in Kosovo over... [a] territorial integrity) and also in Chapter 7, Article I, Paragraph 1 (a) where the parties including Kosovo are invited to reaffirm the "sovereignty and territorial integrity of the Republic of Yugoslavia." 13

8 See Katariina Simonen, Operation Allied Force: A Case of Humanitarian Intervention?, NATO Defense College Occasional Paper (Rome: NDC, 2001). See also G. Gerard Ong, "Credibility over Courage: NATO's Mis-Intervention in Kosovo," Journal of Strategic Studies 26, no. 1 (2003): 82-83.

9 Evgueni Primakov, Le Monde après le 11 Septembre et la Guerre en Irak (Paris: Presses de la Renaissance, 2003), 127.

10 Ibid., 129; Pierre Jolicoeur, "Qui reconnaît l'indépendance du Kosovo doit en assumer les conséquences," Points de Mire 9, no. 4 (May 2008), available at www.ieim.uqam.ca/IMG/pdf/ Jolicoeur_vol9no4.pdf.

11 Frederic Labarre, "The Kosovo War in a Constructivist Perspective," Connections: The Quarterly Journal 6, no. 3 (Fall 2007): 52-53; Jolicoeur, "Qui reconnaît l'indépendance du Kosovo doit en assumer les conséquences."

12 S/RES/1244 (1999), 11 (a).

13 Interim Agreement for Peace and Self-Government in Kosovo (Rambouillet Agreement), March 1999, www.state.gov/www/regions/eur/ksvo_rambouillet_text.html. 
Serbia endorsed UNSCR 1244 after abdicating to NATO's Operation Allied Force. By virtue of the linkage established in UNSCR 1244, Serbia found itself forced to agree with the principles of Rambouillet (which Serbia had repudiated in March 1999). It also meant that there was an apparent continuity in the international community's desire to preserve the territorial integrity of the FRY. Any discussion pertaining to the future of Kosovo as part of or separate from the FRY would have to take into consideration these two principles in the context of security as provided by and institutions developed under international administration. ${ }^{14}$

The wording of the resolution incorporates two worldviews: that of state rights (with an emphasis on territorial integrity) ${ }^{15}$ and that of human rights (with an emphasis on self-determination of Kosovars within the FRY). The latter was mandated to be carried out first by the international community and subsequently be transferred to local jurisdiction. The political settlement between the parties was shaped by the relationship between the local (now indigenous) administration of Kosovo and Belgrade. ${ }^{16}$ As such, it can be interpreted as an attempt by "post-modern" states to soothe the outrage of the "modern" members on the UNSC at NATO's intervention over Kosovo. UNSCR 1244 is simultaneously a peacebuilding plan imposed on Kosovo by the UNSC and a measure to restore NATO/US - Russia relations after the NATO intervention.

\section{The Rupture of Norms: Post-UDI Conflict Management}

Still, instead of working through the issues, Kosovo Albanians unilaterally declared their independence from Serbia in direct contravention of international legal practice, in contravention to the principles of the Rambouillet Accords, flouting UNSCR 1244 and against the will of the international community, on 17 February 2008. Nevertheless, it was recognized by major powers: the United States, France, Turkey, the United Kingdom, Germany, Australia and Belgium all formally recognized Kosovo within a week. The current sum of countries that have followed suit stands at 101, with Egypt as the most recent country to recognize Kosovo on 26 June $2013 .^{17}$

Kosovo's UDI in February 2008 did not doom post-Cold War conflict management per se; instead, the rapid recognition of independence by the main Euro-Atlantic powers is to blame. Russia and China felt that they had been double-crossed. In the nine years between UNSCR 1244 and Kosovo's UDI, the international community had held the principle of territorial integrity sacrosanct. Now, those same major powers promptly recognized Kosovo's independence. Nadia Arbatova, speaking at an ISODARCO meet-

14 S/RES/1244 (1999), annex 2, para. 5 and para. 8.

15 S/1244/1999, preamble: "Reaffirming the commitment of all Member States to the sovereignty and territorial integrity of the Federal Republic of Yugoslavia and the other States of the region, as set out in the Helsinki Final Act and annex 2," Annex 1, and Annex 2, para. 8. This is in addition to statements pertaining to territorial integrity of FRY contained in the Rambouillet Accords.

16 S/1244/1999, para 11, d), e) and f).

17 www.kosovothanksyou.com (9 August 2013); www.utexas.edu/cola/centers/european_studies/ _files/PDF/Secession\%20Paper\%20Joseph.pdf. 
ing in 2002, summarized the thinking of Russia's political elite: NATO's intervention in Kosovo had as its objective the creation of a "NATO state" in the middle of Europe all along. ${ }^{18}$ The International Crisis Group seems to echo this sentiment, saying that Kosovo's UDI "was the outcome of a long, internationally-supervised process and based on a framework designed by UN Special Envoy Martti Ahtisaari that set in place its internal structure and statehood." 19 The General Assembly asked the International Court of Justice to submit an advisory opinion on the international legality of the provisional government of Kosovo's UDI in October 2010. It concluded that although the UDI "did not violate international law, ${ }^{20}$ this did not necessarily mean that Kosovo could separate from the FRY. However, the ICJ was not mandated to offer this opinion:

The Court considers that it is not necessary, in the present case, to resolve the question whether, outside the context of non-self-governing territories and peoples subject to alien subjugation, domination and exploitation, the international law of self-determination confers upon part of the population of an existing State a right to separate from that State, or whether international law provides for a right of "remedial secession" and, if so, in what circumstances. It recalls that the General Assembly has requested the Court's opinion only on whether or not the declaration of independence is in accordance with international law. ${ }^{21}$

In addition, the ICJ seemed to be judging the UNSC instead of the legality of the UDI. The Court interpreted and applied the meaning of UNSCR 1244. It found that since the UNSC did not render an amendment to UNSCR 1244 on the occasion of its meeting of 18 February 2008 in which it could have rejected any possibility of UDI, one was consequently not prohibited. ${ }^{22}$ The ICJ basically explained that the unilateral character of the declaration was not illegal, that "independence" was not necessarily tantamount to separation and that the UNSC had the option of invalidating the declaration at any time.

18 Notes taken by the author from a speech by Nadia Arbatova to the ISODARCO group, January 2002. This impression is corroborated by the apparently unfortunate wording of a cable between US Ambassador Christopher Dell to Deputy Assistant Foreign Secretary Phil Gordon, leaked by The Guardian on December 9, 2010; the cable, dated January 29, 2010, begins; "Integrating Kosovo Serbs into Kosovo society and preserving the country's territorial integrity is central to Kosovo's and the region's long-term stability and has been a core U.S. policy objective since 1999." This suggests that the aim of US policy since 1999 had in fact been the independence of Kosovo. Edward P. Joseph, Senior Fellow at Johns Hopkins' School of Advanced International Studies, claims that this was a "highly coordinated event backed by the US and leading European capitals", cf. Edward P. Joseph, "Kosovo's Independence and Secessionist Movements: Dire Consequences or Benign Impact?" Secession Redux: Lessons for the EU (Washington D.C.: Center for Transatlantic Relations, March 2013), 6.

19 International Crisis Group, "Abkhazia: The Long Road to Reconciliation," Europe Report 224 (10 April 2013), 1.

20 International Court of Justice, Accordance with International Law of the Unilateral Declaration of Independence with respect of Kosovo, Summary, 2010/2, July 22, 2010, 15.

21 Ibid., 8.

22 Ibid., 9. 
This development shaped the conflict management model of the post-Cold War years. In fact, we can speak of a new era of conflict management that harkens back to the self-help paradigm of Realpolitik. The Kosovo episode gravely affected the other preventive and post-conflict components of conflict management. Since it appeared that a certain portion of the UNSC engaged in peace operations to effect democratic regime change, conflict prevention (in the form of preventative deployments) and peacebuilding schemes became suspect. The UN tried to re-focus its activities around conflict prevention and peacebuilding, but its efforts in those areas remain limited. ${ }^{23}$ On 7 June 2001, the UN Secretary General reported on "Prevention of Armed Conflict" in which peacekeeping operations had only a preventative function. ${ }^{24}$ Later on, the UNSC requested from the Secretary General, via Resolution 1645 of 20 December 2005, that a Peacebuilding Commission be created within the UN Secretariat. ${ }^{25}$

Carrie Manning has pointed out that peacebuilding is actually state-building. In other words, a predominant vision of the state will tend to operate under international tutelage. This vision is permeated by liberal democratic ideals, that is, pushing for the "practical establishment of state authority throughout the national territory." 26 In essence, UNSCR 1244 appears designed to precipitate this very outcome within the territorial integrity of the FRY, lest it be forgotten that only effective state control can provide national minorities with effective protection under international law. ${ }^{27}$ Unsure of the guarantees of the international community, the provisional authorities of Kosovo felt safer in declaring independence.

Legally, the recognition of Kosovo's UDI was a further evolution of the international legal principle of uti possidetis, which had permitted the dissolution of Yugoslavia (not the secession of its autonomous provinces). In recognizing Kosovo's independence,

23 Fred Tanner, "Conflict Prevention and Conflict Resolution: The Limits to Multilateralism," International Review of the Red Cross 839 (30 September 2000), www.icrc.ch. More critically, the recent Peacebuilding Commission (PBC) has limited its engagement to six countries (Burundi, the Central African Republic, Liberia, Guinea, Guinea-Bissau and Sierra Leone), none of which are within the immediate sphere of interest claimed by the five permanent members of the Security Council. The PBC has pushed this agenda at every turn in its reports. The fact that no new countries are set up on the PBC's agenda, that its reports pertain so widely to organizational matters and aim at the transition of UN missions out of the countries under scrutiny without evidence that peace has been established, suggests that the UN is also being pushed out of the peacebuilding arena.

24 Report of the Secretary General, Prevention of Armed Conflict, S/2001/574, paras. 81-85.

25 UN Security Council Resolution establishing a Peacebuilding Commission, S/1645/2005, para. 23.

26 Carrie Manning, "Local-level Challenges to Post-Conflict Peacebuilding," International Peacekeeping 10, no. 3 (2003), 26.

27 John Williams, Legitimacy and the Rise and Fall of Yugoslavia (London: McMillan, 1998), 33. 
some major powers in fact decreed that the principle of uti possidetis also applies to a non-autonomous province of the FRY. ${ }^{28}$

Certain members of the international community may have felt that continued stability could be secured through recognition. Were Kosovo deemed a "special case," it would not lead to "copycat secessionism."

"Special cases" should not encourage "Pandora's boxes." But it has, and the United States and other supporters of Kosovo's independence have had a difficult time attempting to defend the faulty logic that self-determination is acceptable in areas of their strategic interest and that the sanctity of sovereign borders must be upheld where it is not. ${ }^{29}$

In fact, the contagious effect of the Kosovo UDI has quickly spread to other minority groups seeking self-determination, not only in the former Yugoslavia, but in the former Soviet Union as well. Hensel, Allison and Khanani demonstrated in 2006 that the uti possidetis principle has not, in its application, prevented territorial disputes or challenges from occurring. ${ }^{30}$ The Kosovo Model of conflict management, thus modified by the UDI, prompted the Kosovo Serbs to seek independence, encouraged the creation of a Republic of Sandjak and the secession of Republika Srpska from Bosnia and Herzegovina. $^{31}$ It stood to inspire Abkhazia, South Ossetia, Transdnistria and perhaps NagornoKarabakh as well. Yet, now that the Kosovo Serbs want to rejoin Serbia proper, the UNSC has found itself unable to address this "new" issue. ${ }^{32}$

The Kosovo Model of conflict management appears inherently flawed insofar as it has abused the procedures of the UN and the principles of multilateralism as a forum for oppressed minorities and an equalizer of power among states. By its very nature, multilateral conflict management allows states to maintain harmonious relations because it offers predictability. Since the Kosovo Model was tainted by the defection of the

28 Pierre Jolicoeur, "Reconnaissance étatique, autodétermination et sécession: les problèmes que posent les cas du Kosovo et de l'Ossétie du Sud en droit international," Panel C4(a) "International Law and Institution, 2," Canadian Political Science Association (CPSA), 13-15 June 2012, Edmonton.

29 Michael Rossi, "Five Inconvenient Truths about Kosovo," 17 July 2013, www.transconflict.com/2013/07/five-inconvenient-truths-about-kosovo-177.

30 Paul Hensel, Michael Allison and Ahmed Khanani, Territorial Integrity Treaties, Uti Possidetis, and Armed Conflict over Territory, paper presented at the 2006 Shambaugh Conference "Building Synergies: Institutions and Cooperation in World Politics," University of Iowa, 13 October 2006, 24.

31 Milos Subotic, "Northern Kosovo: The Underestimated Conflict at the Heart of the Balkan Powder Keg," 4 August, 2011; and Mark Lowen, "Kosovo Tense after Deadly Clash on Serbian Border," BBC News, 6 July 2011. The cases of Sandjak and the Respublika Srpska are mentioned in the proceedings of some workshops of the Regional Stability in South East Europe, a Study Group of the Partnership for Peace Consortium of Defense Academies and Security Studies Institutes (2004-2009), see www.bmlvs.gv.at and www.pfpconsortium.org.

32 According to the work programme of the UN Security Council, available at www.un.org, there have been only two debates on UNMIK at the UNSC in 2013, one in June and one in August. 
Western powers from those principles, it no longer offers predictable outcomes. Bringing a dispute or a crisis before the UNSC now seems pointless, even imprudent.

Roughly half the world's countries have answered Kosovo's call for recognition, including some NATO countries. This suggests that for some of these countries, nonrecognition was decided on merit. While this did not produce a schism in NATO, one can still perceive a rough alignment between new and old NATO members, with the former against (and, therefore, in support of the FRY's territorial integrity) and the latter more or less in support of Kosovo independence. For some countries, such as Slovakia and Belgium, the fear that a Pandora's box might trigger secessionist movements in their own countries echo Russia's concerns about its restive regions. The inherent mistrust is therefore directed at minority independence claimants and small group irredentism that do not follow the agenda of their sponsors. This mistrust is likely to extend past any successful declaration of independence as in Kosovo. The future health of international and regional relations is, therefore, put in peril because the motivations of small groups cannot be trusted.

Moreover, the multilateral agenda has been irreparably damaged. The capacity of states to engage in constructive problem-solving through the UN has been exhausted for the time being. The ability of peoples and small countries to internationalize a dispute and appeal to the UN system is correspondingly affected as, in many cases, the assent of the UNSC, that is, consensus among the permanent five, will be required. The outcome will accentuate the fragmentation of the international system and put a premium to self-help.

Three observations thus characterize the post-Kosovo UDI conflict management model:

- Western powers on the UNSC, and NATO members, could not be trusted to keep their word when it came to the preservation of territorial integrity.

- Provisional or transitional governments' intentions and commitments to the prerequisites of international conflict management would henceforth appear suspect to major powers.

- The capacity of groups in distress to internationalize a dispute, to raise awareness of tensions or to call on the international community to intervene would be contingent upon the degree of control that the major powers could maintain over the conflict management agenda. Since the multilateral solution became discredited, a propensity for "self-sufficiency conflict management" would take hold.

The next section illustrates each observation with concrete examples.

\section{Three Consequences of Post-UDI Conflict Management from the Perspec- tive of the Caucasus}

Georgia's South Ossetian adventure in 2008 only makes sense in the context of Kosovo's UDI. As a country dealing with a dual threat of fragmentation from South Ossetia and Abkhazia, Georgia may have felt genuinely threatened in its territorial integrity 
when it saw the international community welcoming Kosovo's independence. Its attempt at forcibly reintegrating South Ossetia and Abkhazia was intended to mitigate the threat of "copycat" separatism. At that precise, fleeting moment, Georgian, Russian and Western interests could have been reconciled by denouncing Kosovo's independence. That did not happen. NATO countries' credibility was staked on the triple promise of respect for Georgian territorial integrity, NATO membership and assurance that Kosovo would not become an example to follow by Abkhazia and South Ossetia. Russia's unilateral intervention in the Georgian-South Ossetian conflict produced a "Kosovo in reverse" and exposed Western duplicity when it refused to recognize the independence of Abkhazia and South Ossetia.

\section{The New Mistrust of Multilateralism}

Even if there had been the will, no one could have hoped to present the Georgia-South Ossetia dispute to the UNSC. The legacy of Kosovo made that impossible and Russia, least of all, would have been able to trust the word of the NATO members on the UNSC. As Keohane and Nye remind us, in multilateral settings, states that flout international law may be unable to secure future agreements with other states, groups or minorities. ${ }^{33}$ Since the Kosovo Model of conflict management no longer offers any predictable outcome, Russia could no longer invoke the intervention of the UN under Chapter VI or VII for the threat to international peace that it perceived on its southern flank, even if it had wanted to. There would either have been a deadlock or the plans that could be obtained through negotiation at the UNSC could not be expected to function, as the word of the Western powers could not be trusted.

The UNSC resolutions pertaining to Georgia in the aftermath of the Kosovo UDI contain language reflecting such mistrust. For example, S/1808/2008

reaffirms the commitment of all Member States to the sovereignty, independence and territorial integrity of Georgia within its internationally recognized borders and supports all efforts by the United Nations and the Group of Friends of the Secretary-General, which are guided by their determination to promote a settlement of the GeorgianAbkhaz conflict only by peaceful means and within the framework of the Security Council resolutions. ${ }^{34}$

The emphasis on the last part of the paragraph is significant and seeks to establish the primacy of the UNSC as the principal organ of conflict management with the UN Observer Mission in Georgia (UNOMIG) as its principal instrument. UNSCR 1808 comes nearly two months after Kosovo's UDI and two weeks after NATO's promise to Georgia that it would one day be a member of the alliance. It would be the last UNSC resolution before the war in August.

The fact that no multilateral institution could deal with even the post-conflict phase of conflict management is illustrated by the celerity with which France, as president of

33 Robert O. Keohane and Joseph S. Nye, Jr., "Power and Interdependence Revisited," International Organization 41, no. 1 (1987), 743.

34

Para. 1. (emphasised by the authors). 
the EU Council, seized upon the role of mediator, negotiating a six-point agreement between Georgia and Russia. The agreement did not mention Georgia's territorial integrity, gravely impeded after Russia's and a handful other countries' recognition of the independence of Abkhazia and South Ossetia. ${ }^{35}$ Even if it was on behalf of the EU, it was Nicolas Sarkozy who interceded directly between the parties, knowing full well that with the polarity of opinions in the EU regarding the responsibility for hostilities, no resolution of any significance could have been obtained from an EU mechanism. ${ }^{36}$ The only EU instrument presently deployed in Georgia is the EU Monitoring Mission (EUMM), which reports to the EU Council. As an observer mission, it differs little from UNOMIG, which ceased its operations in 2009 and is subject to the consent of the parties. As such, the EU Council lamented the fact that Russia was not meeting its commitments with regard to the EUMM's access to Georgia's breakaway enclaves. ${ }^{37}$

The final two UNSC resolutions pertaining to Georgia were curt: UNSCR 1839, in October 2008, merely extended UNOMIG until 15 February 2009 and UNSCR 1866, on 13 February 2009, extended UNOMIG until June 2009 and fully endorsed the six-point agreement reached by the French EU Council presidency. Georgia has not been the object of a UNSC resolution since. ${ }^{38}$

As a result, Georgia is locked in an asymmetrical negotiation position vis-à-vis Russia within the Geneva Talks framework. Although the format includes the EU, OSCE and UN as well as Georgian, Russian and the American participation, talks are deadlocked. Nona Mikhelidze has argued that this is a function of format and content, but it is clear that the Russian side has been able to forestall UN and OSCE monitoring on the ground, leaving little for the negotiators of these two organizations to contribute in the Geneva talks. ${ }^{39}$ The lethargic activity on the Caucasus at the UNSC and limited scope of the EU mission (itself agreed with the consent of fractious EU members) are symptomatic of the mistrust in multilateralism by major powers.

35 Kai Olaf Lang, "The Old Fears of New Europeans," in The Caucasus Crisis: Perceptions and Policy Implications for Germany and Europe, ed. Hans Henning-Schröder (Berlin: SWP RP 9, 2008), 31 .

36 Ibid., 31-33. Council of the European Union, Extraordinary European Council of: Conclusions of the Presidency, 12594/08, Brussels, 1 September 2008, para. 4, states that the mediation was carried out by the European Union, but given the fact that the six-point agreement led to the Geneva forum of bilateral negotiations, this hardly amounts to a multilateral solution.

37 Council of the European Union, Conclusions of the Council on the South Caucasus, $3149^{\text {th }}$ Foreign Affairs Council Meeting, 27 February 2012, para. 18.

38 Oscar Pardo Sierra, "A Point of No Return? Georgia and the EU One Year after the August War," Central Asia Caucasus Analyst 11, no. 15 (2009), 3. The only international monitoring presence in Georgia is the EUMM.

39 Nona Mikhelidze, "The Geneva Talks over Georgia's Territorial Conflicts: Achievements and Challenges," Istituto Affari Internazionali 10, no. 25 (2010), 3-5. 


\section{Mistrust of Liberation Movements and Small Powers}

The lukewarm enthusiasm for intervention by major powers is an indication of mistrust in the motives and intentions of small powers and liberation movements. This phenomenon is difficult to measure empirically, but it is felt relative to the enthusiasm for intervention in the 1990s, especially in the Balkans, on the European mainland. While a decade of inconclusive nation-building (what Manning equated with peacebuilding) in Iraq and Afghanistan has also taken its toll; major Western powers do not believe that small powers and liberation movements share their appetite for democracy and good governance. ${ }^{40}$ The cavalier disregard by Kosovo's provisional government of the UNSC's writ has astounded many, but no more than the attempt of the Kosovo authorities to subjugate its predominantly Serbian parts and prevent its partitioning.

In the case of the Caucasus, there is evidence that some new NATO countries emboldened Georgia to take action against South Ossetia and that certain persons greatly contributed to assuring - without evidence - that NATO would support Georgia's attempt at forcibly re-integrating its breakaway regions. ${ }^{41}$ Georgia's responsibility for the hostilities has been acknowledged by the international community, stalling its NATO ambitions. ${ }^{42}$ Jeremy Pressman argues that alliances exist expressly to restrain recalcitrant countries and to shape their policies around more or less harmonious positions reflective of an organization's values. ${ }^{43}$ If those values are not shared by the potential new members, then the enlargement drive will come to a stop. In effect, it has come to a stop for Georgia.

Similarly, Russia's presence in Georgia can be interpreted as a form of close protection of minorities seeking emancipation. In fact, the narrative of Russia's intervention in the South Ossetian and Abkhazian crises mirrors that of the NATO intervention in Kosovo: central authorities that abuse the right to self-determination of their minorities calling for humanitarian intervention that resulted in the independence of breakaway re-

40 John Herbst, "Failed States and the International Community Ten Years after 9/11: A Shifting Paradigm?" in Preventing Conflict, Managing Crises: European and American Perspectives, ed. Eva Gross et al. (Washington DC: Center for Transatlantic Relations, 2011), 10. See also Pew Research Center, The American-Western European Values Gap, 17 November 2011, 4, where a minority of the American, British and French public supports helping other nations. The Pew Research Center concludes that the values' gap is subsiding.

41 Frederic Labarre, "Russian Capabilities, '888' (the Russian-Georgian War of August) and the Impact on the Alliance," SITREP: The Journal of the Royal Canadian Military Institute 68, no. 6 (2008), 13.

42 Rui Gomes da Silva, rapporteur, "Georgia and NATO," NATO Parliamentary Assembly, 180 PNCP 09 E Rev.1, 2008, para. 34. The report puts equal blame on Russia and Georgia, reflecting the split in opinions in the Assembly.

43 Jeremy Pressman, Warring Friends: Alliance Restraint in International Politics (Ithaca, NY: Cornell University Press, 2005); and Thomas Risse-Kappen, "Collective Identity in a Democratic Community: The Case of NATO," in The Culture of National Security: Norms and Identity in World Politics, ed. Peter J. Katzenstein (New York: Columbia University Press, 1996), 357-399. 
gions. ${ }^{44}$ Yet it can also be argued that Russia's presence in the region is aimed at maintaining control over the policies of its Caucasus allies. Evidence for this is the allusion made by Paata Zarakeishvili that Moscow has convinced some of its allies in the region not to recognize Abkhazia and South Ossetia. ${ }^{45}$ Although Tbilisi would call that "occupation" of its sovereign territory, de jure it would seem no different than the presence of KFOR troops in Kosovo for Serbia. De facto, the difference is that KFOR was a multinational mission, whereas Russian peacekeepers answer directly to Moscow. ${ }^{46}$

Russia's presence in Armenia responds to critical regional geostrategic needs and may also fulfill certain guarantees, but inevitably ties Yerevan's policies to the preferences of Moscow. The relative ease with which Azerbaijan has been able to support Georgian territorial integrity can partly be explained as a function of the restraining factors of the Russia-Armenia relationship. ${ }^{47}$ In other words, Russia's presence constrains Armenia because it is worried about the outcome of the latter's independent policies.

As explained above, the mistrust expressed by major powers of the intentions and motives of self-determination movements and small powers is difficult to measure empirically, but between the NATO Summits of 2008 in Bucharest and Lisbon in 2010 analysts have detected a greater focus on the preferences of great powers than any other time since the end of the Cold War. ${ }^{48}$

Conflict management in the Caucasus is a function of neither institutions nor international law, but rather of states. Regional hegemony is the driver for conflict prevention, as monopolized by powerful actors that use it to assert idiosyncratic regional interests. This leaves smaller actors in relative isolation and positions them asymmetrically vis-àvis the hegemon. That leaves little room for political maneuvering, including choosing ones alliances. Indeed, the breakaway regions of Georgia are independent in name only. Had they followed the example of Kosovo, they might have found themselves in an international "no-country's land." Michael Rossi has shown how Kosovo's independence did not bring about regional stability and also did not bring the human and cultural emancipation it sought. For example, Kosovo is unable to gain membership in nongovernmental organizations such as the International Olympic Committee (IOC) or the Fédération Internationale de Football Association (FIFA). ${ }^{49}$ If the Kosovo Model of conflict management was meant to bring stability, it failed. If it was designed to bestow

44 "Interview with Dr. Viacheslav Chirikba, Advisor on Foreign Policy to the President of Abkhazia," Russian Analytical Digest 45, no. 8 (2008), 8.

45 Paata Zakareishvili, "Georgia's Relationship with Abkhazia," Caucasus Analytical Digest 7, no. 9 (2010), 9.

46 Pierre Jolicoeur, "Le maintien de la paix par la Russie dans la CEI," in Guide du maintien de la paix 2005, ed. Jocelyn Coulon (Montréal: Athéna éditions, 2004), 77-98.

47 Sergey Markedonov, "Caucasus Conflict Breaks Old Rules of the Game," Russian Analytical Digest 45, no. 8 (2008), 5.

48 Pierre Jolicoeur and Frederic Labarre, "La Sécurité européenne et les Relations Europe-Russie à la Lumière du Concept stratégique de l'OTAN adopté à Lisbonne," in Europe et Sécurité après le Traité de Lisbonne, ed. Ian Roberge (Bruxelles: Bruylant, 2013), 129.

49

Michael Rossi, Five Inconvenient Truths about Kosovo. 
genuine independence on oppressed minorities, it failed as well; the Abkhaz and Ossetian applications of this model are evidence to this end.

\section{Welcome back, Realpolitik}

Realpolitik is supplanting multilateralism in conflict management. Intervention becomes driven only by political will and national interest. The multilateral flavor of intervention is nowhere to be seen; the crises of the Arab Spring of 2011 have illustrated this point clearly. Widespread condemnation of the various dictatorships by Western powers has accompanied the uprisings in North Africa and the Middle East notwithstanding that only two cases have seen intervention.

NATO's Operation Unified Protector effectively supported the rebels in Libya against Muammar Qaddafi's regime. Even this intervention betrayed the lack of appetite of the United States, which promptly abdicated the leadership role to France and Great Britain. Unified Protector was hardly emblematic of alliance cohesion; barely a third of the Allies participated, and France and Great Britain shouldered the heaviest burden. ${ }^{50}$ Further, the expulsion of Islamist rebels from Mali in 2013 was handled unilaterally by France.

International intervention in Syria has not been prevented by deadlock at the UNSC. If self-help returns as a conflict management technique, the ability of international organizations to protect small powers and minorities will remain hostage to the strongest power.

Furthermore, the reputation of major powers may also suffer. For example, international opinion on France's operation in Mali suffers from a continental divide. African nations largely see the intervention in a positive light; the Middle East is more ambivalent, with only 41 percent of states approving of France's actions. ${ }^{51}$ The United States' security policies have recently relied more on their technological prowess than on their soft power of persuasion, as exemplified by the extra-legal use of drones. This attitude has garnered few friends around the world and subsequently hampered US ability to claim the moral high ground in multilateral conflict management. ${ }^{52}$ The fact that countries such as France, Great Britain and especially the United States are less likely to cultivate multilateral approval of the use of military force for purposes of conflict management renders the legitimization of action problematic. ${ }^{53}$

On the whole, "a multipolar and less governable world is emerging." will shape relations to come more than multilateralism; for one, NATO, although re-

50 Keir Giles, The State of the NATO-Russia Reset (Oxford: Conflict Studies Research Centre, September 2011), 22-24.

51 Pew Research Center, As Mali Votes, Mixed Reception to French Intervention from Publics in Africa and the Middle East, 25 July 2013, 2.

52 Pew Research Center, Global Opinion of Obama Slips, International Policies Faulted, 13 June 2012, 16-18.

53 Ibid., 32.

54 Antonio Missiroli, ed., Enabling the Future: EU Military Capability 2013-2025, Report 16 (Paris: EU Institute for Security Studies, 2013), 19. 
spected, depends on active US involvement, which is currently wanting. The EU's ability to shape the strategic environment according to its interests is hampered by the reluctance of its members to cooperate in military matters involving coercive conflict management. ${ }^{55}$ The UN's case, as described above, reveals an institution that has abdicated its peacekeeping and peace enforcement imperatives. One can therefore conclude that the gap in conflict management will be taken up by the capabilities of nation-states in accordance with their willingness to intervene and their interests. ${ }^{56}$ In this regard, it is interesting to note the commonality of purpose between the French White Paper of December 2008 and the British Comprehensive Strategic Review issued in March $2008 .^{57}$ It is even more interesting to note how the scope of global French strategic interests mirrors that of the EU Institute of Strategic Studies' assessment, ${ }^{58}$ which suggests that France and Great Britain are shouldering the destiny of the EU's conflict management priorities.

Another indication that state-centered international politics is on the rise is the fleeting attempt by Russia to establish new European security architecture. ${ }^{59}$ This attempt, which did not succeed, aimed to rebalance European conflict management instruments that oriented towards NATO. ${ }^{60}$ President Dmitri Medvedev's New European Security Architecture was not all that new: it basically reiterated the precepts of the $1975 \mathrm{Hel}-$ sinki Final Act, whose provisions on the inviolability of borders are so precious to Russia. ${ }^{61}$ Faced with Western Europe's indifference at the proposal, Russia is now banking on a Eurasian Union. ${ }^{62}$ Meanwhile, Euro-Atlantic powers are no closer to reforming the international institutions that are supposedly meant to shape the global strategic environment.

It is too soon to tell whether these initiatives will forge "strategic blocks" reminiscent of the Cold War. In the meantime, there is bound to be little cooperation among great powers on conflict management and few prospects for small powers and minorities under duress to have their voices heard and resolve their grievances through international institutional mechanisms. The implications are clear for the Caucasus: when not on their

55 Ibid., 10-13.

56 "The French White Paper on Defence and National Security," CSS Analyses in Security Policy 46 , no. 3 (2008), 1-2.

57 Ibid., 1-2, reiterated in Her Majesty's Government's Securing Britain in an Age of Uncertainty: Strategic Security and Defence Review, October 2010, 12.

58 Missiroli, ed., Enabling the Future, 17, compared with CSS Analyses, passim, 2. www.strategicstudiesinstitute.army.mil/pdffiles/pub958.pdf.

59 Richard Krickus, Medvedev's Plan: Giving Russia a Voice but not a Veto in a New European Security System (Carlisle, PA: Strategic Studies Institute, December 2009), 18-22.

${ }^{60}$ Keir Giles, Russia's National Security Strategy to 2020 (Rome: NATO Defense College, June 2009), 6-7.

${ }^{61}$ Marcin Kaczmarski, "The Russian Proposal for a New European Security System," CES Commentary 11, 16 October 2008, 2.

62 Boris Kuznetsov, "Russo-Georgian Rapprochement: A Light at the End of the Tunnel," Vienna: LandesverteidigungsAkademie, July 2013, 115. Notes from a presentation to the Regional Stability in the South Caucasus Study Group (RSSC SG), delivered March 2013. 
own to face the perils of contemporary international relations, they will be subject to the unrestricted sway of a local hegemon.

\section{Conclusion}

Conflict management has been morphing ever since doubt arose about the UN's ability to muster the willingness and capacity necessary to engage in peace enforcement. The Kosovo conflict management experience by the Euro-Atlantic powers attempted to put the spirit of the Charter of the United Nations and the normative (respect for human rights) aspects of the Helsinki Final Act before the letter of international law (inviolability of borders, respect for territorial integrity and national sovereignty).

The Euro-Atlantic powers were faced with a moral dilemma in Kosovo: do things right, or do the right thing. By disobeying custom, they called into question the foundations of international law with respect to self-determination, secession and independence movements. Because international law supports the edifice of multilateral institutions, even multilateralism has become suspect. Whereas multilateralism offered small powers and even groups a chance to air their grievances constructively, a return to state-centered solutions of conflict management means that eventually, "the weak will have to suffer what they must," to paraphrase Thucydides.

The Kosovo Model would have worked had the intentions of the framers of UNSCR 1244 been upheld, had the Kosovo Provisional Government been reprimanded for their UDI and had the UNSC been more deliberate in its prohibition of UDI in cases such as Kosovo, which fall outside the hitherto accepted doctrine of uti possidetis. The premature and unnecessary recognition of Kosovo by major Western powers is the bad example, not the conflict management model that was in use until the UDI.

Western powers recognized Kosovo after more than a decade of promising to preserve Serbia's territorial integrity. This represents duplicity of the highest order. More specifically, the UDI cast oppressed groups in a negative light, as unreliable partners in conflict management. Finally, if Operation Allied Force was a victory of human rights over state rights, the state has recovered its lost prestige by taking the mantle of conflict management in the post-UDI world. The unpredictability of the contemporary strategic environment is a source of threat for everyone, and although many argue that the economic recession and the rise of Brazil, Russia, India and China as regional and global economic powers shoulder their share of responsibility for upsetting the global equilibrium of power, the Kosovo crisis, taken in its entirety, exemplifies that the state-centered approach is, for the moment, the best guarantee against unreliable institutions and partners, big or small. 


\section{Bibliography}

"The French White Paper on Defence and National Security." CSS Analyses in Security Policy 46, no. 3 (2008): 1-2.

Abkhazia: The Long Road to Reconciliation In Europe Report. International Crisis Group, 2013.

Accordance with International Law of the Unilateral Declaration of Independence with respect of Kosovo In Summary. International Court of Justice, 2010.

As Mali Votes, Mixed Reception to French Intervention from Publics in Africa and the Middle East. Pew Research Center, 2013.

Baylis, John, and Steve Smith. The Globalization of World Politics. 2nd ed. Oxford: OUP, 1998.

Conclusions of the Council on the South Caucasus In 3149th Foreign Affairs Council Meeting. Council of the European Union, 2012.

Cooper, Robert. The Breaking of Nations: Order and Chaos in the 21st Century. London: Grove Press, 2004.

da Silva, Rui Gomes. Georgia and NATO In NATO Parliamentary Assembly., 2008.

Extraordinary European Council of: Conclusions of the Presidency. Brussels: Council of the European Union, 2008.

Fröhlich, Manuel. Keeping Track of UN Peace-keeping: Suez, Srebrenica, Rwanda and the Brahimi Report In Max Planck Yearbook of United Nations Law. Vol. 5., 2001.

G. Ong, Gerard. "Credibility over Courage: NATO's Mis-Intervention in Kosovo." Journal of Strategic Studies 26, no. 1 (2003): 82-83.

Giles, Keir. The State of the NATO-Russia Reset. Oxford: Conflict Studies Research Centre, 2011.

Global Opinion of Obama Slips, International Policies Faulted. Pew Research Center, 2012.

Goodwyn, Craufurd, and Michael Nacht. Beyond Government. Boulder: Westview Press, 1995.

Hensel, Paul, Michael Allison, and Ahmed Khanani. "Territorial Integrity Treaties, Uti Possidetis, and Armed Conflict over Territory." In 2006 Shambaugh Conference "Building Synergies: Institutions and Cooperation in World Politics". University of Iowa, 2006. 
Herbst, John. "Failed States and the International Community Ten Years after 9/11: A Shifting Paradigm?" In Preventing Conflict, Managing Crises: European and American Perspectives, 10. Washington DC: Center for Transatlantic Relations, 2011.

Interim Agreement for Peace and Self-Government in Kosovo (Rambouillet Agreement)., 1999.

Jolicoeur, Pierre, and Frederic Labarre. "La Sécurité européenne et les Relations Europe-Russie à la Lumière du Concept stratégique de l'OTAN adopté à Lisbonne." In Europe et Sécurité après le Traité de Lisbonne, 129. Bruxelles: Bruylant, 2013.

Jolicoeur, Pierre. "Le maintien de la paix par la Russie dans la CEI." In Guide du 98maintien de la paix 2005, 77-98. Montréal: Athéna éditions, 2004.

Jolicoeur, Pierre. "Qui reconnaît l'indépendance du Kosovo doit en assumer les conséquences." Points de Mire 9, no. 4 (2008).

Jolicoeur, Pierre. "Reconnaissance étatique, autodétermination et sécession: les problèmes que posent les cas du Kosovo et de l'Ossétie du Sud en droit international." In Panel C4(a) "International Law and Institution, 2". Edmonton: Canadian Political Science Association (CPSA), 2012.

Joseph, Edward P.. Kosovo's Independence and Secessionist Movements: Dire Consequences or Benign Impact? In Secession Redux: Lessons for the EU. Washington D.C.: Center for Transatlantic Relations, 2013.

Kaczmarski, Marcin. "The Russian Proposal for a New European Security System." CES Commentary 11, no. 16 (2008): 2.

Keohane, Robert O., and Joseph S. Nye. "Power and Interdependence Revisited." International Organization 41, no. 4 (1987): 743.

Krickus, Richard. Medvedev's Plan: Giving Russia a Voice but not a Veto in a New European Security System. Carlisle, PA: Strategic Studies Institute, 2009.

Kuznetsov, Boris. Russo-Georgian Rapprochement: A Light at the End of the Tunnel. Vienna: LandesvertidigungAkademie, 2013.

Labarre, Frederic. "Russian Capabilities, '888' (the Russian-Georgian War of August) and the Impact on the Alliance." SITREP: The Journal of the Royal Canadian Military Institute 68, no. 6 (2008): 13.

Labarre, Frederic. "The Kosovo War in a Constructivist Perspective." Connections: The Quarterly Journal 6, no. 3 (2007): 33-61.

Lang, Kai Olaf. "The Old Fears of New Europeans." In The Caucasus Crisis: Perceptions and Policy Implications for Germany and Europe, 31. Berlin: SWP RP 9, 2008. 
Lowen, Mark. Kosovo Tense after Deadly Clash on Serbian Border. BBC News, 2011.

Maloney, Sean M.. Canada and UN Peacekeeping: Cold War by Other Means, 19451970. Toronto: Vanwell Publishing, 2002.

Manning, Carrie. "Local-level Challenges to Post-Conflict Peacebuilding." International Peacekeeping 10, no. 3 (2003): 26.

Markedonov, Sergey. "Caucasus Conflict Breaks Old Rules of the Game." Russian Analytical Digest 45, no. 8 (2008): 5.

Mikhelidze, Nona. "The Geneva Talks over Georgia's Territorial Conflicts: Achievements and Challenges." Istituto Affari Internazionali 10, no. 25 (2010): 3-5.

Missiroli, Antonio. Enabling the Future: EU Military Capability 2013-2025. Paris: EU Institute for Security Studies, 2013.

Nye, Joseph S.. Understanding International Conflicts. Vol. 4th ed. New York: Longman, 2003.

Pressman, Jeremy. Warring Friends: Alliance Restraint in International Politics. Ithaca, NY: CUP, 2005.

Prevention of Armed Conflict In Report of the Secretary General., 2001.

Primakov, Evgueni. Le Monde après le 11 Septembre et la Guerre en Irak. Paris: Presses de la Renaissance, 2003.

Risse-Kappen, Thomas. "Collective Identity in a Democratic Community: The Case of NATO." In The Culture of National Security: Norms and Identity in World Politics, 357399. New York: Columbia University Press, 1996.

Rossi, Michael. Five Inconvenient Truths about Kosovo., 2013.

Russia's National Security Strategy to 2020. National Security Council of the Russian Federation, 2009.

Securing Britain in an Age of Uncertainty: Strategic Security and Defence Review., 2010.

Sierra, Oscar Pardo. "A Point of No Return? Georgia and the EU One Year after the August War." Central Asia Caucasus Analyst 11, no. 15 (2009): 3.

Simonen, Katariina. Operation Allied Force: A Case of Humanitarian Intervention? In Athena Papers. Vol. 1. Garmisch-Partenkirchen: Partnership for Peace Consortium of Defense Academies and Security Studies Institutes, 2004.

Subotic, Milos. Northern Kosovo: The Underestimated Conflict at the Heart of the Balkan Powder Keg., 2011. 
SUMMER 2014

Tanner, Fred. Conflict Prevention and Conflict Resolution: The Limits to Multilateralism In International Review of the Red Cross., 2000.

UN Security Council Resolution establishing a Peacebuilding Commission., 2005.

Williams, John. Legitimacy and the Rise and Fall of Yugoslavia. London: McMillan, 1998.

Zakareishvili, Paata. "Georgia's Relationship with Abkhazia." Caucasus Analytical Digest 7, no. 9 (2010): 9. 